Case Reports in
Gastroenterology
Case Rep Gastroenterol 2020;14:443-447

DOI: $10.1159 / 000508852$

Published online: August 26, 2020
(C) 2020 The Author(s)

Published by S. Karger AG, Base www.karger.com/crg

This article is licensed under the Creative Commons Attribution-NonCommercial 4.0 International License (CC BY-NC) (http://www.karger.com/Services/OpenAccessLicense). Usage and distribution for commercial purposes requires written permission.

\title{
Black Esophagus in the Setting of Alcohol Abuse after External Beam Radiation
}

\author{
Smit S. Deliwala ${ }^{a} \quad H a r i n i ~ L a k s h m a n^{a} \quad$ Douglas D. Congdon ${ }^{b}$ \\ Mamoon M. Elbedawi ${ }^{c}$ Ghassan Bachuwa ${ }^{a}$ Grigoriy E. Gurvits ${ }^{d}$ \\ aDepartment of Internal Medicine, Michigan State University at Hurley Medical Center, \\ Flint, MI, USA; ${ }^{b}$ Department of Pathology, Michigan State University at Hurley Medical \\ Center, Flint, MI, USA; 'Division of Gastroenterology, Department of Internal Medicine, \\ Michigan State University at Hurley Medical Center, Flint, MI, USA; dDivision of \\ Gastroenterology, Department of Internal Medicine, New York University School of \\ Medicine/Langone Medical Center, New York, NY, USA
}

\section{Keywords}

Black esophagus - Acute esophageal necrosis · Gurvits syndrome $\cdot$ Necrotizing esophagitis

\section{Abstract}

Acute esophageal necrosis (AEN), black esophagus, or Gurvits syndrome is a rare clinical disorder characterized by a striking endoscopic appearance of necrotic esophageal mucosa, universally affecting the distal esophagus and ending abruptly at the gastroesophageal junction. It has been gaining traction as a demonstrable cause of upper gastrointestinal bleeding in the 21 st century. Its pathophysiology is multifactorial affecting men and the elderly disproportionally, with a mortality rate nearing $36 \%$. AEN has been associated with numerous conditions in the past, and we aim to present an unusual case of AEN on the setting of chronic alcohol use. 


\section{Case Reports in Gastroenterology}

Case Rep Gastroenterol 2020;14:443-447 DOI: $10.1159 / 000508852$

(c) 2020 The Author(s). Published by S. Karger AG, Basel www.karger.com/crg

Deliwala et al.: Black Esophagus after External Beam Radiation

\section{Introduction}

Acute esophageal necrosis (AEN), black esophagus (BE), or Gurvits syndrome is a rare clinical disorder characterized by a striking endoscopic appearance of necrotic esophageal mucosa that involves the distal esophagus, may extend proximally, and ends abruptly at the gastroesophageal junction [1]. Historically, BE was described in the autopsy reports from the mid-20th century [2], followed by live endoscopic findings in the 1990s [3] and then organized into a distinct syndrome in 2007 [1]. AEN has been gaining traction as a demonstrable cause of upper gastrointestinal bleeding in the 21st century. Its pathophysiology is a combination of tissue hypoperfusion (seen in low flow states and thromboembolic phenomena), a massive influx of corrosive gastric contents (notable in chemical paresis from alcohol intoxication or ketoacidosis and gastric outlet obstruction from associated ulcer disease), and impaired local defense barriers (seen in malnourished patients and immunocompromised conditions) [4]. AEN is more common in males and the elderly, and it is associated with cardiovascular, pulmonary, renal, and hepatic disease, alcohol abuse, diabetic ketoacidosis, malnourishment, and malignancy [5]. Late complications include esophageal stricture or stenosis in nearly $10 \%$ of the patients, typically amendable to endoscopic dilatation. We present a novel case of AEN in the setting of alcohol abuse in a patient with a multisystem disorder who recovered with conservative therapy.

\section{Case Presentation}

A 62-year-old cachectic male was admitted to the hospital with sudden left-sided pressure-like chest pain and agitated behavior at his living facility. His past medical history included chronic obstructive pulmonary disease, bronchiolitis obliterans organizing pneumonia, squamous cell lung carcinoma requiring stereotactic body radiation therapy, gastroesophageal reflux disease, gastroduodenal ulcers, coronary artery disease, cigarette smoking, and chronic alcohol use with his last drink $48 \mathrm{~h}$ prior. On physical examination, he appeared ill and malnourished, afebrile, hypertensive to 163/114, tachycardic at 131, and tachypnea to 22 breaths/min saturating at $100 \%$ on room air. Laboratory analysis was remarkable for hemoglobin $8.4 \mathrm{~g} / \mathrm{dL}$, platelets 112,000/ $\mathrm{LL}$, serum sodium $129 \mathrm{mEq} / \mathrm{L}$, magnesium 1.4 $\mathrm{mg} / \mathrm{dL}$, serum albumin $2.7 \mathrm{~g} / \mathrm{dL}$, total bilirubin $6.7 \mathrm{mg} / \mathrm{dL}$, direct bilirubin $4.8 \mathrm{mg} / \mathrm{dL}$, alkaline phosphatase $399 \mathrm{U} / \mathrm{L}$, aspartate transaminase $262 \mathrm{U} / \mathrm{L}$, alanine transaminase $107 \mathrm{U} / \mathrm{L}$, international normalized ratio of 1.08 , and serum troponin I was $0.02 \mathrm{ng} / \mathrm{mL}$. Electrocardiogram and computed tomography of the chest for pulmonary embolization were unremarkable. He was diagnosed with acute alcohol withdrawal syndrome and started on lorazepam. The following day, the patient developed coffee ground emesis with a hemoglobin decline to $5.3 \mathrm{~g} / \mathrm{dL}$. He was switched to nil per os, given intravenous proton pump inhibitor, and transfused with two units of packed red blood cells. An emergent esophagogastroduodenoscopy (EGD) revealed black appearing mucosa with scattered ulcerations in the distal esophagus with sharp demarcation at the GE junction and nonspecific gastroduodenitis (Fig. 1). Histology was remarkable for the loss of squamous esophageal epithelium, ulceration changes, and an abundance of inflammatory cells (Fig. 2). The patient was continued on oral esomeprazole and sucralfate with gradual advancement in his diet and discharged to a subacute nursing facility. 


\section{Case Reports in Gastroenterology}

Case Rep Gastroenterol 2020;14:443-447 DOI: $10.1159 / 000508852$

(c) 2020 The Author(s). Published by S. Karger AG, Basel www.karger.com/crg

Deliwala et al.: Black Esophagus after External Beam Radiation

\section{Discussion/Conclusion}

$\mathrm{BE}, \mathrm{AEN}$, or Gurvits syndrome is a rare clinical disorder classically characterized by striking diffuse circumferential black appearing distal esophageal mucosal changes on EGD. Earlier reported incidences of AEN ranged from 0.01 to $0.3 \%$, but the true prevalence is likely higher due to increased recognition and advances in endoscopic detection [6, 7]. Despite the paucity of cases, the last 20 years have seen a surge and ignited interest amongst the specialty for AEN [8]. A MEDLINE literature search for cases, series, and reviews on AEN revealed 38\% of the published material emerging within the past 5 years, over $60 \%$ over the past 10 years, and close to $90 \%$ of all published information on AEN within the past 20 years. A recent study from Japan considered AEN a bona fide cause of gastrointestinal bleeding, with rates nearing $6 \%$ [9].

A total of $90 \%$ of patients present with signs of upper gastrointestinal bleeding, but asymptomatic BE has also been reported $[1,10]$. Endoscopic findings are diagnostic, and tissue biopsy is not required but may be helpful to exclude fungal or viral infections. Histology may reveal necrotic debris, absence of viable epithelium, frequent submucosal involvement, potentially leading to full-thickness lysis, fibrin thrombi, and severe inflammatory changes [1, 6]. Additional endoscopic findings may include duodenal pathology in up to $50 \%$ of the cases [5], likely related to anatomically shared common blood supply branching off the celiac axis. Differential diagnosis of BE includes malignant melanoma, acanthosis nigricans, coal dust deposition, pseudomelanosis, and melanocytosis of the esophagus. The staging system of BE addresses progression and complications and has been used to classify the natural history of this condition $[1,11]$. Management of AEN is largely supportive aimed at correcting the underlying processes, hemodynamic resuscitation, nil per os restriction, and aggressive anti-reflux therapy with proton pump inhibitors. Blind passage of nasogastric tube should be avoided in fear of tissue perforation, while empirical antibiotic therapy should be considered in cases of immune compromise, clinical decompensation, or suspected tissue perforation. Surgical intervention is reserved for perforation with resultant mediastinitis and abscess formation, a finding in less than $7 \%$ of patients. Esophageal stricture or stenosis formation occurs in over $10 \%$ of the cases and seems to parallel the extent of co-existing duodenal pathology [5].

The overall prognosis of AEN is poor, with close to a third of patients dying from associated critical illness, while mortality specific to AEN is low at 6\% [1]. Our patient with significant underlying cardiovascular and pulmonary disease likely suffered an acute esophageal injury in the setting of alcohol abuse with significant dehydration and hypovolemia and resultant decreased mucosal perfusion, massive corrosive reflux from gastric paresis, and impaired local defense barriers from chronic malnourishment. His recent radiation therapy to the thoracic cavity may have augmented the susceptibility of the esophagus to the initial insult. Finally, prompt recognition of AEN and management of co-existing medical conditions translated into effective care for this fragile patient.

\section{Statement of Ethics}

Informed consent was obtained for this case report. 
Case Reports in
Gastroenterology

Case Rep Gastroenterol 2020;14:443-447

DOI: $10.1159 / 000508852$

(c) 2020 The Author(s). Published by S. Karger AG, Basel www.karger.com/crg

Deliwala et al.: Black Esophagus after External Beam Radiation

\section{Conflict of Interest Statement}

The authors have no conflicts of interest to report.

\section{Funding Sources}

No financial disclosures to report.

\section{Author Contributions}

Smit S. Deliwala: Conception, design, draft, analysis, and revision. Harini Lakshman: Acquisition, analysis, and draft. Douglas D. Congdon: Acquisition, interpretation, and analysis. Mamoon M. Elbedawi: Acquisition, interpretation, and analysis. Ghassan Bachuwa: Draft, interpretation, and analysis. Grigoriy E. Gurvits: Draft, interpretation, analysis, review, and revision.

\section{References}

1 Gurvits GE, Shapsis A, Lau N, Gualtieri N, Robilotti JG. Acute esophageal necrosis: a rare syndrome. J Gastroenterol. 2007 Jan;42(1):29-38.

2 Etienne JP, Roge J, Delavierre P, Veyssier P. [Esophageal necrosis of vascular origin]. Sem Hop. 1969 May;45(23):1599-606. French.

3 Goldenberg SP, Wain SL, Marignani P. Acute necrotizing esophagitis. Gastroenterology. 1990 Feb;98(2):4936. https://www.gastrojournal.org/article/0016-5085(90)90844-Q/pdf.

4 Gurvits GE. Black esophagus: acute esophageal necrosis syndrome. World J Gastroenterol. 2010 Jul;16(26):3219-25.

5 Gurvits GE, Cherian K, Shami MN, Korabathina R, El-Nader EM, Rayapudi K, et al. Black esophagus: new insights and multicenter international experience in 2014. Dig Dis Sci. 2015 Feb;60(2):444-53.

6 Lacy BE, Toor A, Bensen SP, Rothstein RI, Maheshwari Y. Acute esophageal necrosis: report of two cases and a review of the literature. Gastrointest Endosc. 1999 Apr;49(4 Pt 1):527-32.

7 Augusto F, Fernandes V, Cremers MI, Oliveira AP, Lobato C, Alves AL, et al. Acute necrotizing esophagitis: a large retrospective case series. Endoscopy. 2004 May;36(5):411-5.

8 Jacobsen NO, Christiansen J, Kruse A. Incidence of oesophageal necrosis in an autopsy material. APMIS. 2003 May;111(5):591-4.

9 Yasuda H, Yamada M, Endo Y, Inoue K, Yoshiba M. Acute necrotizing esophagitis: role of nonsteroidal antiinflammatory drugs. J Gastroenterol. 2006 Mar;41(3):193-7.

10 Rejchrt S, Douda T, Kopácová M, Siroký M, Repák R, Nožička J, et al. Acute esophageal necrosis (black esophagus): endoscopic and histopathologic appearance. Endoscopy. 2004 Dec;36(12):1133.

11 Kimura Y, Seno H, Yamashita Y. A case of acute necrotizing esophagitis. Gastrointest Endosc. 2014 Sep;80(3):525-6. 
Case Reports in Gastroenterology
Case Rep Gastroenterol 2020;14:443-447

DOI: 10.1159/000508852

(c) 2020 The Author(s). Published by S. Karger AG, Basel www.karger.com/crg

Deliwala et al.: Black Esophagus after External Beam Radiation

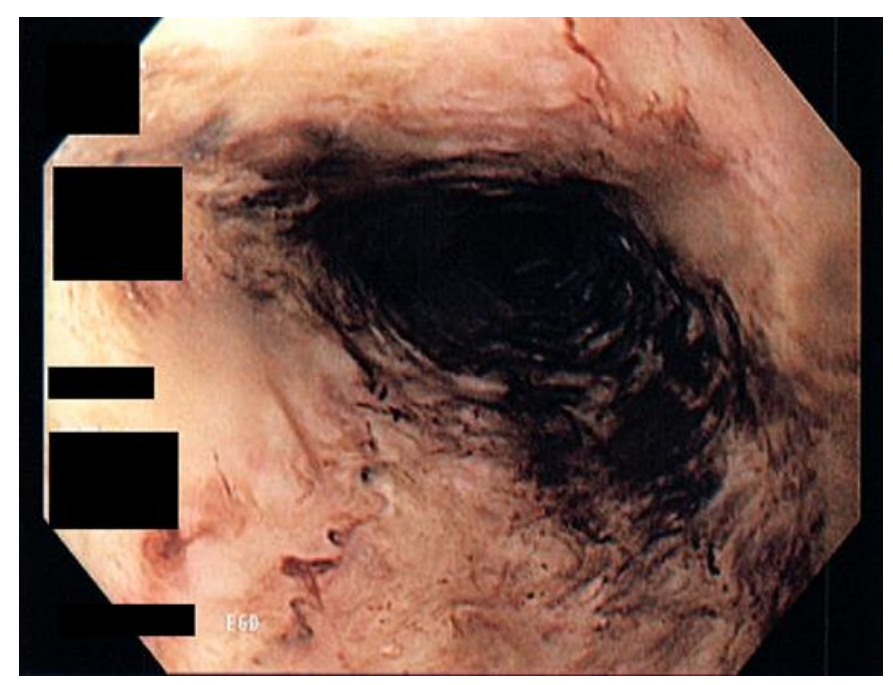

Fig. 1. EGD revealing a black necrotic appearance of the lower esophagus. EGD, esophagogastroduodenoscopy.

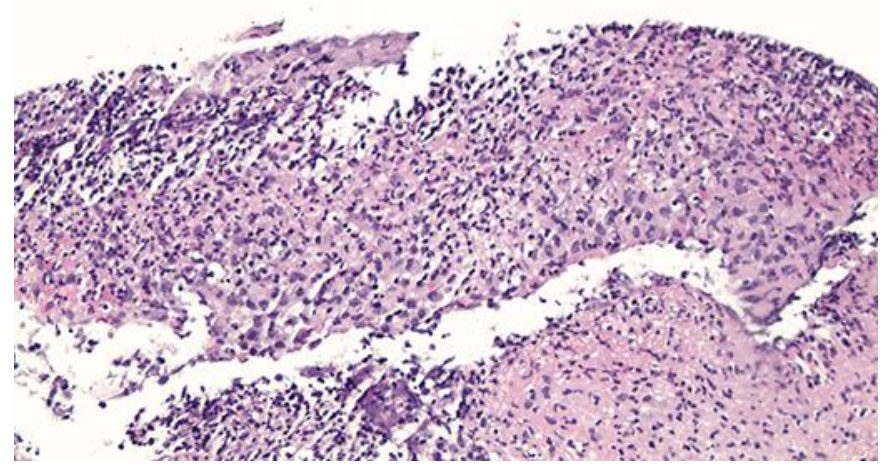

Fig. 2. Histologic identification of AEN or BE: hematoxylin and eosin (H\&E) staining demonstrating ulceration, absent epithelium, and widespread leukocyte infiltration at 100× magnification. AEN, acute esophageal necrosis; BE, black esophagus. 